\title{
Behavior of Hollow Thin Welded Tubes Filled with Sand Slag Concrete
}

\author{
Noureddine Ferhoune, ${ }^{1}$ Meriem Senani, ${ }^{2}$ and Abdelhamid Guettala ${ }^{2}$ \\ ${ }^{1}$ University of Larbi Ben M'hidi, 04000 Oum El Boughi, Algeria \\ ${ }^{2}$ University of Mohamed Khider Biskra, 07000 Biskra, Algeria \\ Correspondence should be addressed to Noureddine Ferhoune; ferhoune.noureddine@gmail.com
}

Received 4 May 2016; Revised 27 June 2016; Accepted 29 June 2016

Academic Editor: Ana S. Guimarães

Copyright (C) 2016 Noureddine Ferhoune et al. This is an open access article distributed under the Creative Commons Attribution License, which permits unrestricted use, distribution, and reproduction in any medium, provided the original work is properly cited.

\begin{abstract}
This paper presents the axial bearing capacity of thin welded rectangular steel stubs filled with concrete sand. A series of tests was conducted to study the behavior of short composite columns under axial compressive load; the cross section dimensions were 100 $\times 70 \times 2 \mathrm{~mm}$. A total of 20 stubs have been tested, as follows: 4 hollow thin welded tubes were tested to axial and eccentric load compression, 4 were filled with ordinary concrete appointed by BO columns, 6 were filled with concrete whose natural sand was completely substituted by a crystallized sand slag designated in this paper by BSI, and 6 were tucked in concrete whose natural sand was partially replaced by a crystallized sand slag called BSII. The main parameters studied are the height of the specimen $(300 \mathrm{~mm}-500 \mathrm{~mm})$, eccentricity of load and type of filling concrete. Based on test results obtained, it is confirmed that the length of the tubes has a considerable effect on the bearing capacity and the failure mode. In all test tubes, fracture occurred by the convex local buckling of steel section due to the outward thrust of the concrete; it was observed that the sand concrete improves the bearing capacity of tubes compounds compared to those filled with ordinary concrete.
\end{abstract}

\section{Introduction}

Concrete-filled steel tube columns have many advantages in terms of their high strength, high ductility, high stiffness, and full usage of construction materials [1-3]. The problem of the behavior of these columns was the subject of several studies in different countries and attracted the attention of many researchers. From all the research conducted, it was found that the type of filling concrete directly affects the capacity and behavior of composite columns [4-8]. Very few experiments are done on built up cold-formed welded steel sections filled with concrete or recycled materials such as slag stone concrete designated here by SSC. The slag stone concrete has been tested under direct compression and was used as a filling material to overcome the undesired effects of imperfections of built up cold-formed sections. The gain in strength was found to reach a value of up to 2 and decreased linearly with the stubs height [9]. The characterization of slag sand concrete has been the subject of some studies; the research works approved the possibility to use the crystallized slag as sand in the composition concrete which may have a competitive performance to conventional concrete [10-12]. The use of slag sand concrete as stuffing materials in steel tubes can improve this behavior, and the use of blast furnace waste as substitute material helps to save a significant share of natural resources and protect the environment. The present work is a contribution to understanding the behavior of hollow thin welded tubes filled with sand slag concrete subjected to axial and eccentric compression.

\section{Experimental Program}

A series of tests was conducted to study the behavior of short composite columns under axial compressive load; the cross section dimensions were $100 \times 70 \times 2 \mathrm{~mm}$, the detail of the section is shown in Figure 1. A total of 20 stubs were tested, as follows: 4 rectangular empty tubes were tested to axial and eccentric load compression, 4 were filled with ordinary concrete, 6 were filled with a concrete substitute natural sand that was completely crystallized by a sand slag, and 6 others were 
TABLE 1: Concrete composition used for filling rectangular steel profiles.

\begin{tabular}{lcccc}
\hline Compositions & Unit & BO & BSI & BSII \\
\hline Cement CPJ 42.5 & $\mathrm{Kg} / \mathrm{m}^{3}$ & 350 & 300 & 300 \\
Water/cement & & & & \\
$\quad$ Calculated & - & 0.5 & 0.81 & 0.61 \\
$\quad$ Real & $\mathrm{Kg} / \mathrm{m}^{3}$ & 725.59 & - & 500 \\
Sand dune 0/2.5 & $\mathrm{Kg} / \mathrm{m}^{3}$ & - & 1540 & 1275 \\
Sand slag granulated 0/3.15 & $\mathrm{Kg} / \mathrm{m}^{3}$ & 1070.67 & - & - \\
Gravel 5/12.5 & & &
\end{tabular}

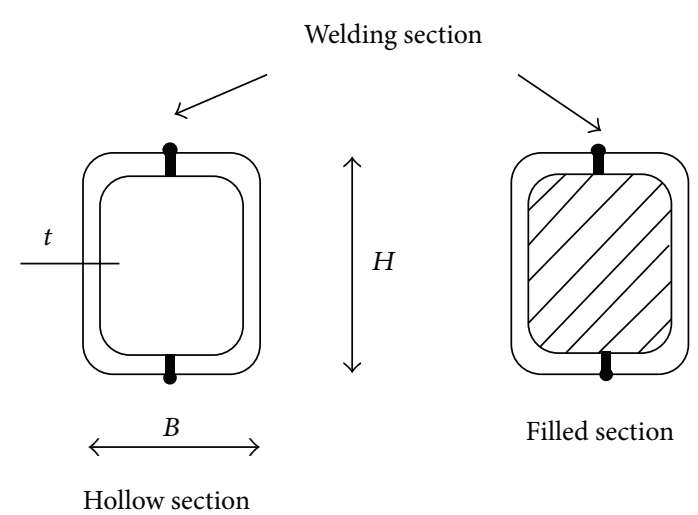

FIGURE 1: Thin cold-formed and welded steel cross section filled with concrete details.

filled with sand slag concrete or natural sand that was partially replaced by a crystallized sand slag. The main objectives of these tests were to clarify the mechanical performance of steel section filled by concrete sand compared to those filled with ordinary concrete. The main parameters studied are the height of the specimen $(300 \mathrm{~mm}-500 \mathrm{~mm})$, type of the applied load (axial or eccentric), and type of concrete filling; the composition of the filling concretes is presented in Table 1.

2.1. Materials Fabrication. The properties of material fabrication of concrete core are shown in Table 1. The steel used for the manufacture of the section is U-profiles of cold rolled thickness $2 \mathrm{~mm}$ whose mechanical characteristics are as follows:

(i) Young modulus $\mathrm{Ea}=205000 \mathrm{MPa}$.

(ii) Yield stress $\sigma e=300 \mathrm{MPa}$.

The rectangular welded steel columns filled with three types of concrete were cast vertically in three layers, each compacted on a vibrating table for 2 to 3 minutes to achieve more even concrete along the length of the specimen. All composite specimens were left in the curing room at an ambient temperature $\left(T=20-25^{\circ} \mathrm{C}\right.$ and humidity rate $\left.=60-70 \%\right)$ for a period of 28 days. Both top and bottom faces of composite stubs were mechanically treated to remove surface irregularities and ensure that both steel and concrete are loaded during test. The 28 days' mean stress of ordinary concrete is 20 MPa, 22.4 Mpa for BSI' and 19 Mpa for BSII concrete mix.
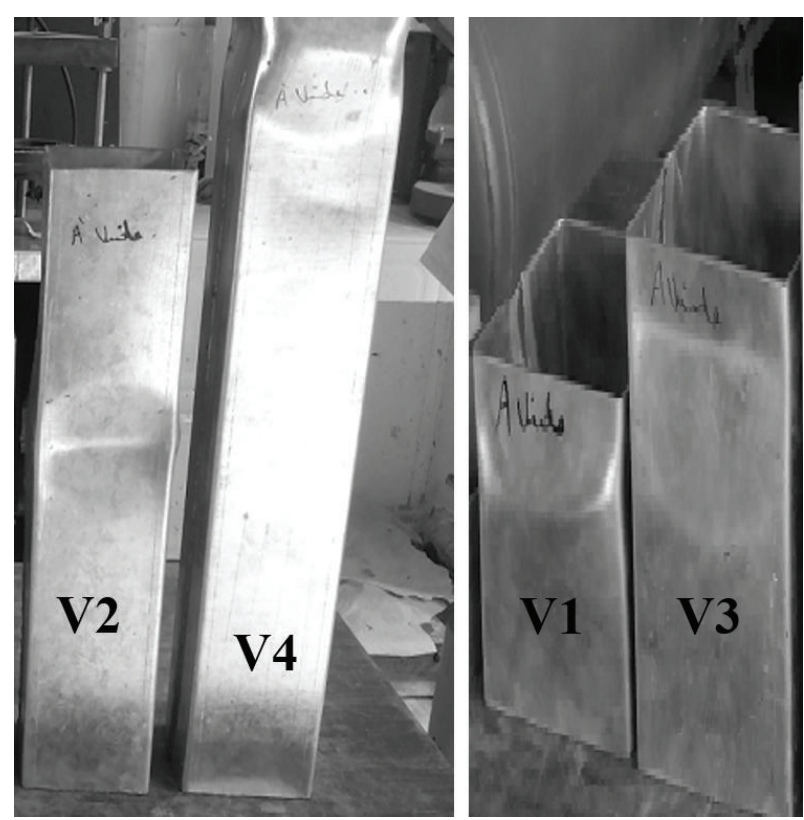

FIgURE 2: Failure mode of empty tubes.

2.2. Physical Properties of Crystallized Sand Slag. The crystallized slag sand use in the composition of concrete is from blast furnace of the El Hadjar steel complex, Algeria. The chemical compositions and the physical properties of the sands and gravel are presented in Tables 2 and 3.

2.3. Test Rig and Procedure. All specimens were tested in a $500 \mathrm{kN}$ compressive machine. Special attention was given to verifying the correct position of the stubs before any loading. The load was applied on the composite section (concrete and steel). Figure 1 shows the detail of columns tested in this work. Both top and bottom faces of composite stubs were mechanically treated to remove surface irregularities. The top and bottom surfaces of the concrete-filled cold-formed steel tube columns were restrained against all degrees of freedom, except for the displacement at the loaded end, which is the top surface, in the direction of the applied load.

\section{Results of Rectangular Empty Stubs Tests}

The load carrying capacities of tested empty steel tubes V1 and V3 tested under concentric load are, respectively, varied from 146 and $138 \mathrm{kN}$ as shown in Table 4; after test, we noted that the large sides of section buckled outwards in contrary to small side. In the case of hollow thin walled tubes V2 and V4 tested to eccentric load, the load carrying capacity decreases by a rate of $9.58 \%$ and $10.14 \%$, respectively, compared to V1 and V3 tubes. The phenomenon observed of the two tested tubes is always local buckling as shown in Figure 2.

\section{Results of Rectangular Filled Stubs Tests}

The test results on the tubes filled with concrete granulated slag (BSI and BSII), made 28 days after the concrete casting 
TABLE 2: Physical properties of sands.

\begin{tabular}{lccccc}
\hline Sand type & $\begin{array}{c}\text { Apparent density } \\
\left(\mathrm{kg} / \mathrm{m}^{3}\right)\end{array}$ & $\begin{array}{c}\text { Specific density } \\
\left(\mathrm{kg} / \mathrm{m}^{3}\right)\end{array}$ & $\begin{array}{c}\text { Porosity in } \\
\text { percentage }\end{array}$ & $\begin{array}{c}\text { Fines modulus } \\
(\mathrm{MF})\end{array}$ & $\begin{array}{c}\text { Water } \\
\text { content in } \\
\text { percentage }\end{array}$ \\
\hline $\begin{array}{l}\text { Dune sand } \\
(0 / 2.5 \mathrm{~mm})\end{array}$ & 1610 & 2650 & 40 & 2.21 & $\begin{array}{c}\text { Sand } \\
\text { equivalent in } \\
\text { percentage }\end{array}$ \\
$\begin{array}{l}\text { Crystallized sand } \\
\text { slag }(0 / 3.15 \mathrm{~mm})\end{array}$ & 1570 & 2630 & 41 & 3.1 & 0.35 \\
\hline
\end{tabular}

TABle 3: Physical properties of gravel.

\begin{tabular}{lccccc}
\hline Gravel type & $\begin{array}{c}\text { Apparent density } \\
\left(\mathrm{kg} / \mathrm{m}^{3}\right)\end{array}$ & $\begin{array}{c}\text { Specific density } \\
\left(\mathrm{kg} / \mathrm{m}^{3}\right)\end{array}$ & $\begin{array}{c}\text { Porosity in } \\
\text { percentage }\end{array}$ & $\begin{array}{c}\text { Water } \\
\text { content in } \\
\text { percentage }\end{array}$ & $\begin{array}{c}\text { Absorption } \\
\text { coefficient } \\
\text { in percentage }\end{array}$ \\
\hline Gravel $(5 / 12.5 \mathrm{~mm})$ & 1300 & 2500 & 48 & 0.79 & 2 \\
\hline
\end{tabular}

TABLE 4: Experimental results of rectangular empty stubs.

\begin{tabular}{lccccc}
\hline Concrete type & Specimen & Height $(\mathrm{mm})$ & $H \times B \times t(\mathrm{~mm})$ & Eccentricity $(\mathrm{mm})$ & Nue $(\mathrm{kN})$ \\
\hline & V1 & 300 & $101.30 \times 69.80 \times 2.30$ & 146 \\
Empty steel tubes & V2 & 500 & $100.10 \times 69.70 \times 2.20$ & 0 & 138 \\
& V3 & 300 & $99.80 \times 70.10 \times 2.30$ & 20 & 132 \\
& V4 & 500 & $100.10 \times 69.40 \times 2.20$ & 20 & 124 \\
\hline
\end{tabular}

TABLE 5: Experimental results of composite columns.

\begin{tabular}{|c|c|c|c|c|c|}
\hline Concrete type & Specimen & Height (mm) & $H \times B \times t(\mathrm{~mm})$ & Eccentricity (mm) & Nue $(\mathrm{kN})$ \\
\hline \multirow{4}{*}{ BO } & PA1-1 & 300 & $100.20 \times 70.10 \times 2.30$ & 0 & 341 \\
\hline & PB1-2 & 300 & $99.90 \times 68.75 \times 2.20$ & 20 & 320 \\
\hline & PA1-3 & 500 & $99.50 \times 69.10 \times 2.20$ & 0 & 330 \\
\hline & PB1-4 & 500 & $99.55 \times 68.75 \times 2.20$ & 20 & 315 \\
\hline \multirow{6}{*}{ BSI } & PA2-1 & 300 & $99.75 \times 69.50 \times 2.20$ & 0 & 385 \\
\hline & PB2-2 & 300 & $99.62 \times 68.06 \times 2.20$ & 20 & 359 \\
\hline & PB2-3 & 300 & $99.62 \times 69.55 \times 2.25$ & 20 & 363 \\
\hline & PA2-4 & 500 & $99.91 \times 69.13 \times 2.30$ & 0 & 368 \\
\hline & PB2-5 & 500 & $98.58 \times 69.75 \times 2.15$ & 20 & 353 \\
\hline & PB2-6 & 500 & $99.37 \times 69.10 \times 2.20$ & 20 & 357 \\
\hline \multirow{6}{*}{ BSII } & PA3-1 & 300 & $99.72 \times 68.50 \times 2.30$ & 0 & 374 \\
\hline & PB3-2 & 300 & $99.82 \times 69.55 \times 2.20$ & 20 & 351 \\
\hline & PB3-3 & 300 & $98.37 \times 69.10 \times 2.20$ & 20 & 349 \\
\hline & PA3-4 & 500 & $100.50 \times 68.55 \times 2.30$ & 0 & 365 \\
\hline & PB3-5 & 500 & $100.63 \times 68.75 \times 2.30$ & 20 & 344 \\
\hline & PB3-6 & 500 & $98.60 \times 69.85 \times 2.30$ & 20 & 341 \\
\hline
\end{tabular}

date, showed the advantage of these types of concrete as tamper member with respect to ordinary concrete (BO). All test results are presented in Table 5 . The load carrying capacity varied from $315 \mathrm{kN}$ to $385 \mathrm{kN}$; the test results of the columns subject to eccentric load confirm the diminution of load carrying capacity when the eccentricity load and stubs height increase.

In Figure 3, we see that the tubes subjected to an axial load with $300 \mathrm{~mm}$ height, filled by sand slag concrete and BSI BSII, give an ultimate load greater than that of columns (BO). The percentage of increase in load is, respectively, $11.43 \%$ and $08.82 \%$. About $500 \mathrm{~mm}$ tubes filled with granulated slag concrete BSI and BSII have increased ultimate load of respectively, $10.33 \%$ and $9.59 \%$, relative to the tube filled with normal concrete $(\mathrm{BO})$.

These test results on the laminated steel tubes welded and cold and thin walls under axial load showed the advantage of the use of slag sand concrete as packing member. Also the height of the tubes has a considerable effect on the bearing capacity; we note that the bearing capacity decreases with increasing the height of the tubes subjected to an axial load whatever the type of filling concrete. 

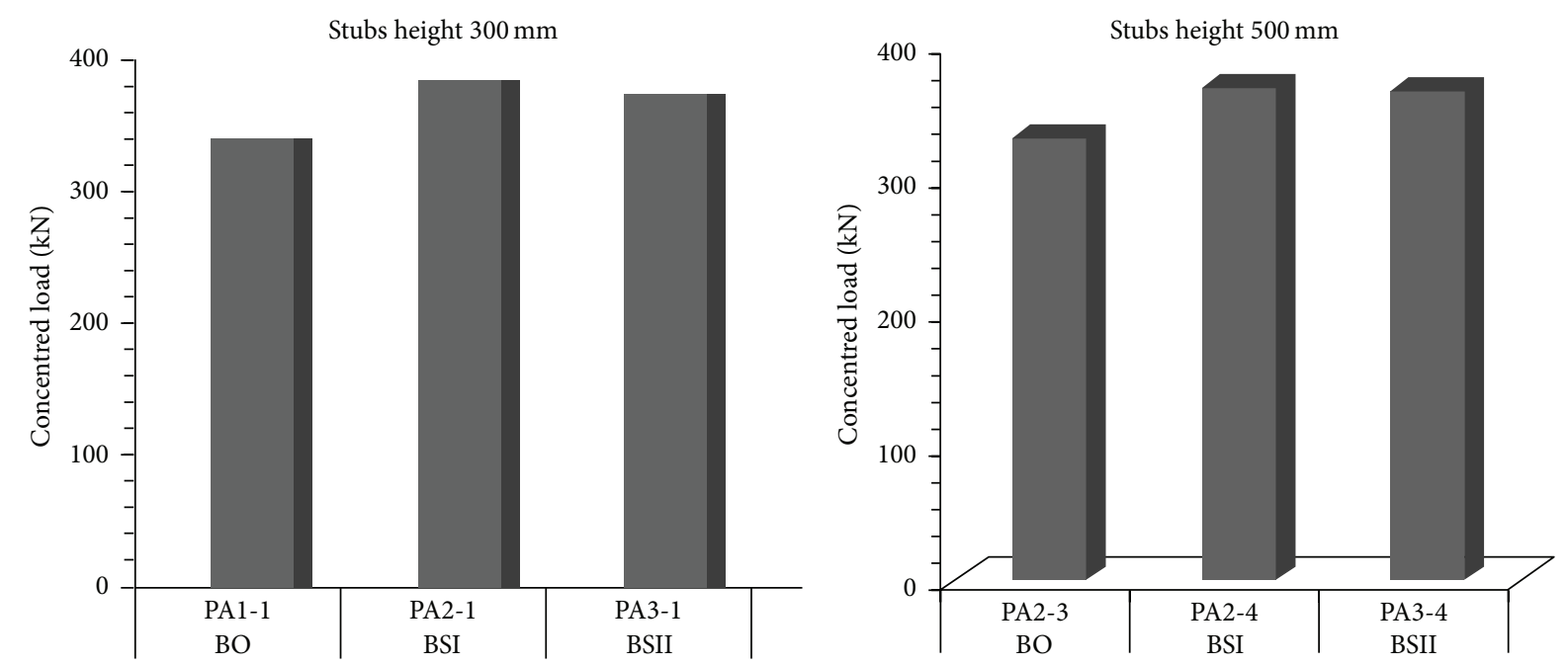

FIGURE 3: Influence of concrete core type on the bearing capacity under axial load.
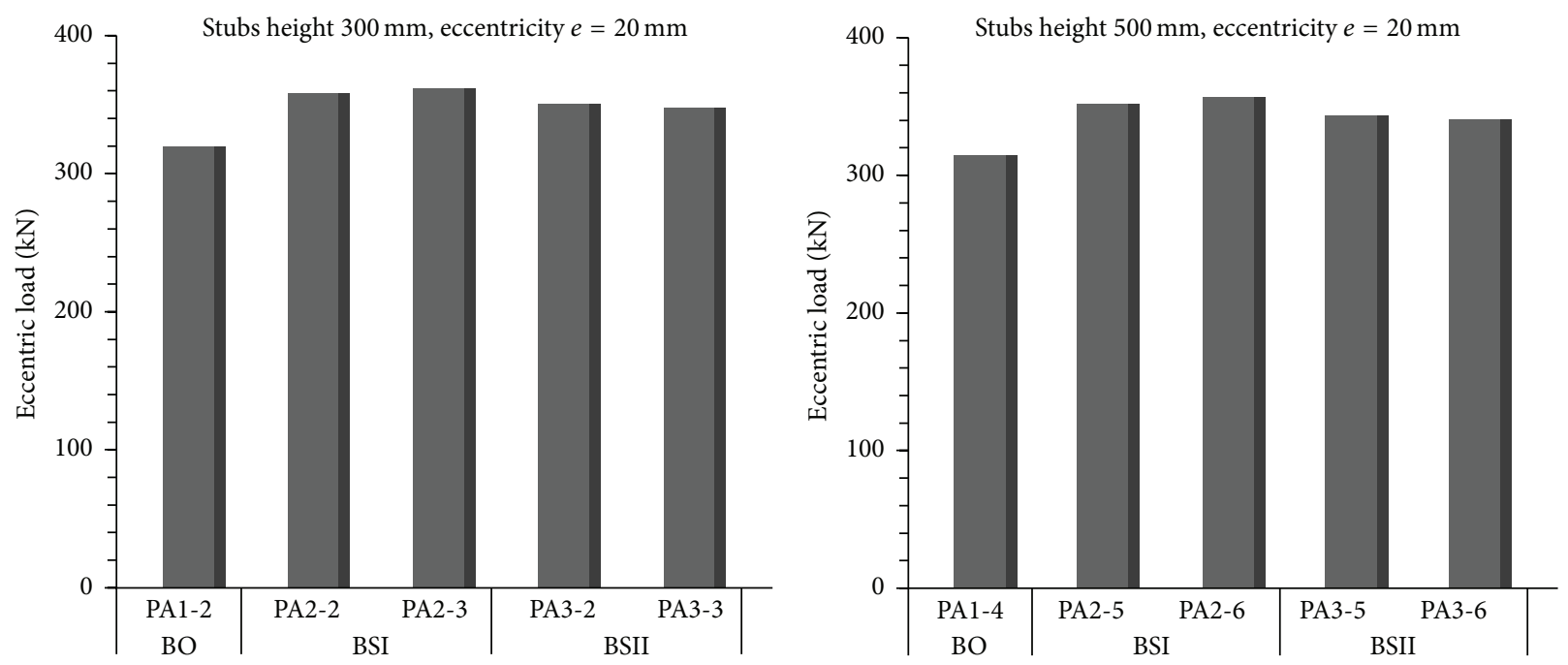

FIGURE 4: Influence of concrete core type on the bearing capacity under eccentric load.

Figure 4 shows the experimental ultimate load tubing made under eccentric loading $(e=20 \mathrm{~mm}$ ). The ultimate load of the stubs height $300 \mathrm{~mm}$ filled by sand BSI concretes and BSII increases, respectively, by the order of $11.36 \%$ and $8.57 \%$, compared to load carrying capacity of column BO and to the tubes with $500 \mathrm{~mm}$ height increase of approximately $11.36 \%$ for BSI and $08.03 \%$ for BSII column compared to BO tube. After comparing the results of different bearing capacity obtained experimentally, we see that the rate of eccentric load has an important influence on the bearing capacity and local buckling forming position. It may be noted that when the eccentricity and stubs height increase the load decreases, as shown in Figures 5 and 6.

Figure 7 shows clearly that the EC4 provides superior load capacity of $1 \% \div 2 \%$ for ordinary concrete-filled tubes under axial loading for stubs height $300 \mathrm{~mm}$ and $500 \mathrm{~mm}$, respectively, and provides a capacity of $0.7 \%$ and $0.9 \%$, respectively, for the tubes of height $300 \mathrm{~mm}$ filled with the granulated slag concrete BSI and BSII. The Euro code 4 gives a good agreement for hollow tubes filled in the case three concrete type.

The comparison of load carrying capacity between filled and empty steel tubes clarifies the benefit of filling hollow thin welded tubes by sand slag concrete as shown in Figure 8 . The rate of increase load is more than twice of empty steel tubes load, which proves that the filling concrete contributes significantly to the increases of bearing capacity and is delaying the problem of instability of these columns.

\section{Plastic Resistance of Composite Columns according to Euro Code 4}

EC3 and EC4 are the most recently completed international standards in steel construction and composite construction, respectively. EC4 provided a simplified method of design for composite columns, which was based on the European 


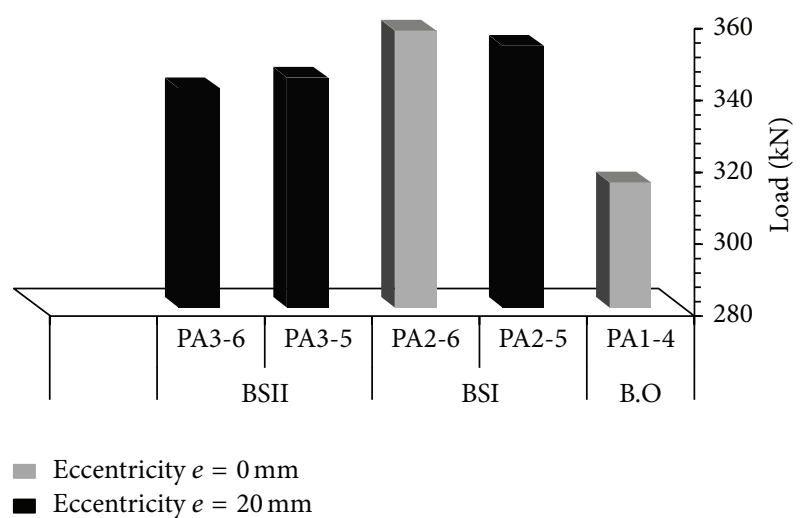

Figure 5: Influence of the eccentricity of load on the bearing capacity (case of the stubs height $300 \mathrm{~mm}$ ).

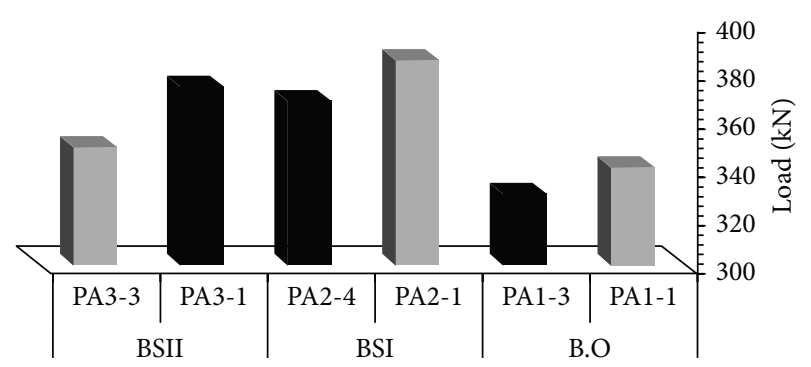

- Eccentricity $e=0 \mathrm{~mm}$

- Eccentricity $e=20 \mathrm{~mm}$

FIGURE 6: Influence of the eccentricity of load on the bearing capacity (case of the stubs height $500 \mathrm{~mm}$ ).

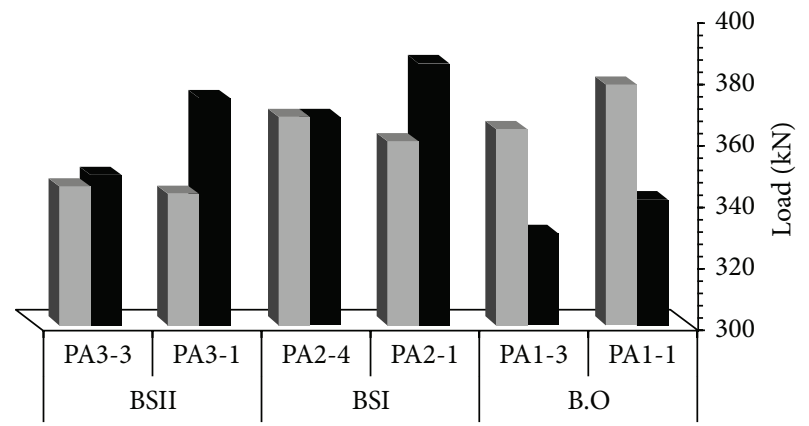

- EC4 load

- Experimental load

FIgURE 7: Experimental load Nue and EC4 load Nuc for the tubes height $500 \mathrm{~mm}$.

buckling curves for the influence of instability and on cross section interaction curves determining the column section's resistance. EC4 covers concrete encased and partially encased steel sections and concrete-filled sections with or without reinforcement. Design procedure of the composite columns considers the second-order effects including imperfections and ensures that under the most unfavorable combinations of actions at the ultimate limit state, instability does not occur.

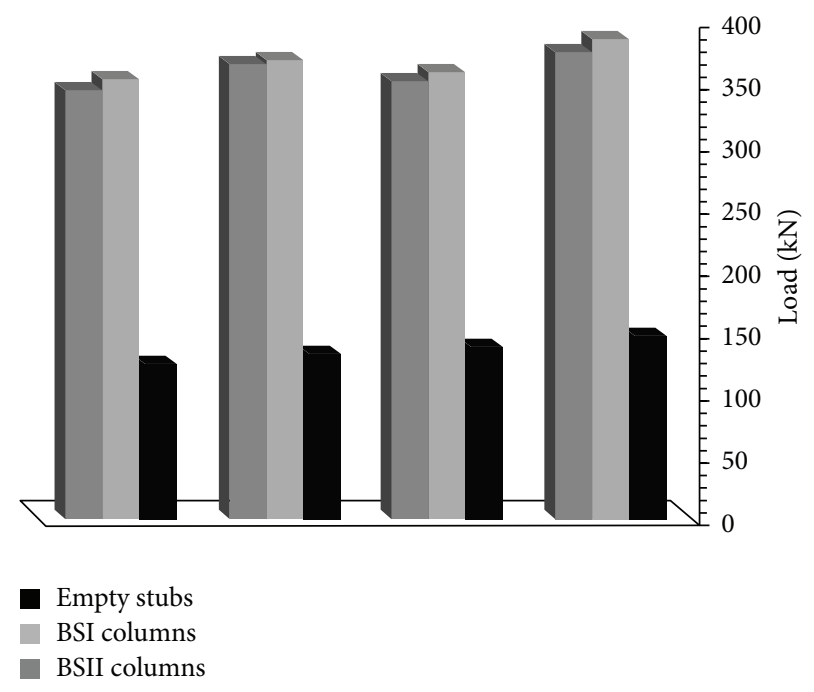

FIGURE 8: Comparison of load carrying capacity between empty and filled stubs.

The plastic resistance to compression $N_{\mathrm{pl}, \mathrm{Rd}}$ of a composite cross section was calculated by adding the plastic resistance of its components:

$$
N_{\mathrm{pl}, \mathrm{Rd}}=\frac{A_{a} f_{y}}{\gamma_{\mathrm{Ma}}}+A_{c}\left(\frac{0.85 f_{\mathrm{ck}}}{\gamma_{c}}\right)+\frac{A_{s} f_{\mathrm{sk}}}{\gamma_{s}},
$$

where $A_{a}, A_{c}$, and $A_{s}$ are the cross-sectional areas of structural steel, concrete, and reinforcement, respectively; $f_{y}$, $f_{\mathrm{ck}}$, and $f_{\mathrm{sk}}$ are, respectively, the yield stress of steel cross section, the strengths of concrete, and the yield stress of steel reinforcement; $\gamma_{\mathrm{Ma}}, \gamma_{c}$, and $\gamma_{s}$ are partial safety factors at the ultimate limit states. The results of load carrying capacity according EC4 are presented in Table 6.

\section{Design Method Proposed by Vrcelj and Uy [13]}

Vrcelj and Uy [13] proposed a design method for the strength calculation of a slender concrete-filled steel box column loaded in compression, when the steel portion of the composite column is affected by local buckling. The following relationship is proposed by Vrcelj and Uy [13]:

$$
N_{\mathrm{clb}}=\alpha_{1 b} N_{c},
$$

where $N_{\mathrm{clb}}$ is the slender column buckling load which incorporates local buckling, $N_{c}$ is the column buckling load, and $\alpha_{1 b}$ is the interaction coefficient to account for local buckling and is in the range $0 \leq \alpha_{1 b} \leq 1.0$.

$\alpha_{1 b}$ is calculated as

$$
\alpha_{1 b}=\frac{\left(100-\rho_{r}\right)}{100},
$$

where the percentage reduction $\rho_{r}$ is given as

$$
\rho_{r}=\left[\frac{\left(N_{c}-N_{\mathrm{clb}}\right)}{N_{c}}\right] \times 100 .
$$


TABLE 6: Load of composite columns according to Euro code 4 compared to experimental load.

\begin{tabular}{|c|c|c|c|c|}
\hline $\begin{array}{l}\text { Concrete } \\
\text { type }\end{array}$ & Specimen & $\begin{array}{l}\text { Stubs height } \\
(\mathrm{mm})\end{array}$ & $\begin{array}{c}\text { Nuc (EC4) } \\
(\mathrm{kN})\end{array}$ & Nuc/Nue \\
\hline \multirow{4}{*}{ BO } & PA1-1 & 300 & 338.23 & 0.99 \\
\hline & PB1-2 & 300 & 310.1 & 0.96 \\
\hline & PA1-3 & 500 & 323.79 & 0.98 \\
\hline & PB1-4 & 500 & 312.30 & 0.99 \\
\hline \multirow{6}{*}{ BSI } & PA2-1 & 300 & 360.05 & 0.93 \\
\hline & PB2-2 & 300 & 353.50 & 0.98 \\
\hline & PB2-3 & 300 & 360.30 & 0.99 \\
\hline & PA2-4 & 500 & 367.07 & 0.99 \\
\hline & PB2-5 & 500 & 342.80 & 0.97 \\
\hline & PB2-6 & 500 & 351.66 & 0.98 \\
\hline \multirow{6}{*}{ BSII } & PA3-1 & 300 & 343.10 & 0.91 \\
\hline & PB3-2 & 300 & 353.40 & 1.01 \\
\hline & PB3-3 & 300 & 351.73 & 1.01 \\
\hline & PA3-4 & 500 & 345.30 & 1.00 \\
\hline & PB3-5 & 500 & 333.85 & 0.97 \\
\hline & PB3-6 & 500 & 314.80 & 0.92 \\
\hline
\end{tabular}

TABLE 7: Load of composite columns according to Vrcelj method.

\begin{tabular}{|c|c|c|c|c|}
\hline Concrete type & Specimen & Stubs height $(\mathrm{mm})$ & $\mathrm{Nu}($ Vrcelj) (kN) & $\mathrm{Nu}$ (Vrcelj)/Nue \\
\hline \multirow{4}{*}{$\mathrm{BO}$} & PA1-1 & 300 & 343.33 & 1.01 \\
\hline & PB1-2 & 300 & 318.41 & 0.99 \\
\hline & PA1-3 & 500 & 328.22 & 0.99 \\
\hline & PB1-4 & 500 & 298.43 & 0.94 \\
\hline \multirow{6}{*}{ BSI } & PA2-1 & 300 & 367.03 & 0.95 \\
\hline & PB2-2 & 300 & 353.82 & 0.98 \\
\hline & PB2-3 & 300 & 352.64 & 0.97 \\
\hline & PA2-4 & 500 & 354.56 & 0.96 \\
\hline & PB2-5 & 500 & 344.75 & 0.97 \\
\hline & PB2-6 & 500 & 345.62 & 0.96 \\
\hline \multirow{6}{*}{ BSII } & PA3-1 & 300 & 354.14 & 0.94 \\
\hline & PB3-2 & 300 & 319.86 & 0.91 \\
\hline & PB3-3 & 300 & 332.78 & 0.95 \\
\hline & PA3-4 & 500 & 354.23 & 0.97 \\
\hline & PB3-5 & 500 & 321.10 & 0.93 \\
\hline & PB3-6 & 500 & 314.64 & 0.92 \\
\hline
\end{tabular}

The results of estimated load carrying capacity of different columns by this above design method are presented in Table 7.

\section{Breakage Mechanism of Filled Tubes}

The failure mode of rectangular hollow tubes filled with three types of concrete study in this work is the local buckling of steel section; the steel section is deformed in a convex manner, as shown in Figures 7 and 8. The local buckling took place in all samples with a small attenuation for longer steel stubs. Both large and small sides buckled outwards. We also noted a breakdown of some welding that occurred at the local buckling formation region has reached the maximum load as shown in Figures 9 and 10.

\section{Discussion}

To investigate the behavior and design of axially loaded concrete sand filled with cold-formed steel tube columns, we present in this work the details of an experimental study of the compressive behavior and axial bearing capacity of thin welded rectangular steel stub columns filled with concrete sand. A comparison between experimental column load strength, load carrying capacity calculated according Euro code 4 designs [14], and design method proposed by Vrcelj 


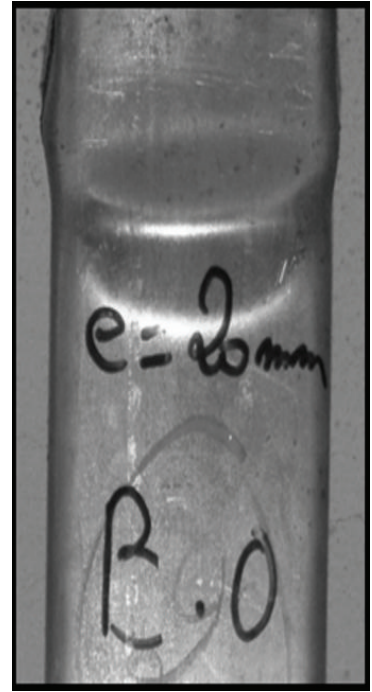

(a) $\mathrm{BO}$ column, eccentricity $e=$

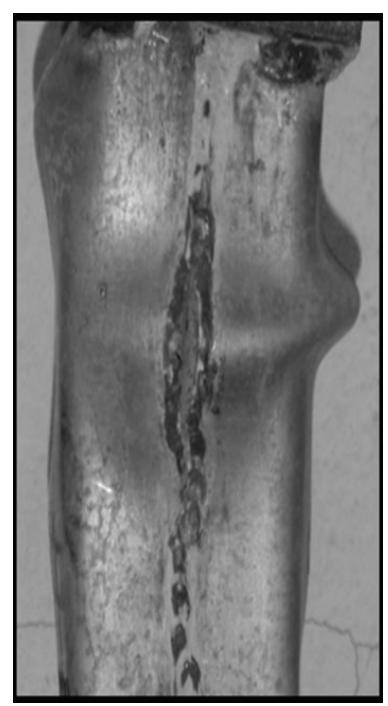

(b) $\mathrm{BO}$ column, eccentricity $e=$ $20 \mathrm{~mm}$

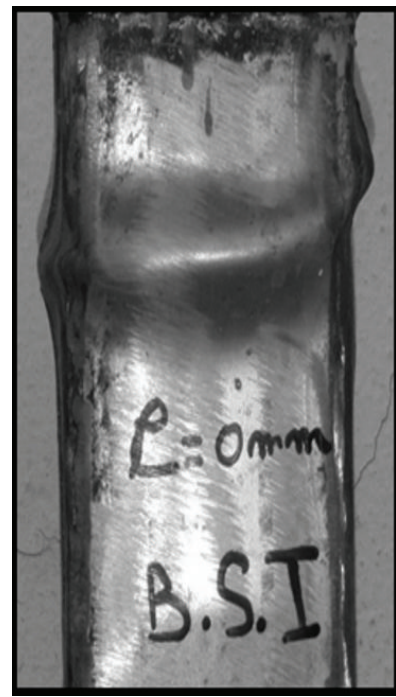

(c) BSI column, eccentricity $e=0$

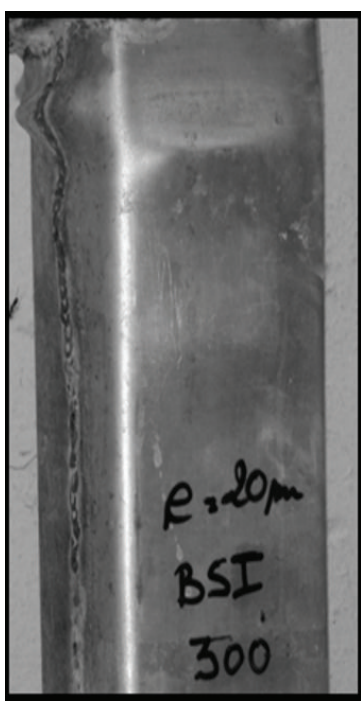

(d) BSI column, eccentricity $e=$ $20 \mathrm{~mm}$

FIGURE 9: Failure mode of BO and BSI columns.

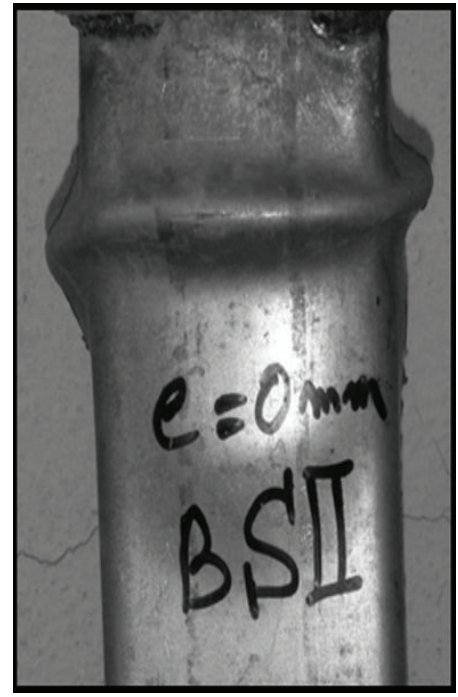

(a) BSII column, eccentricity $e=0$

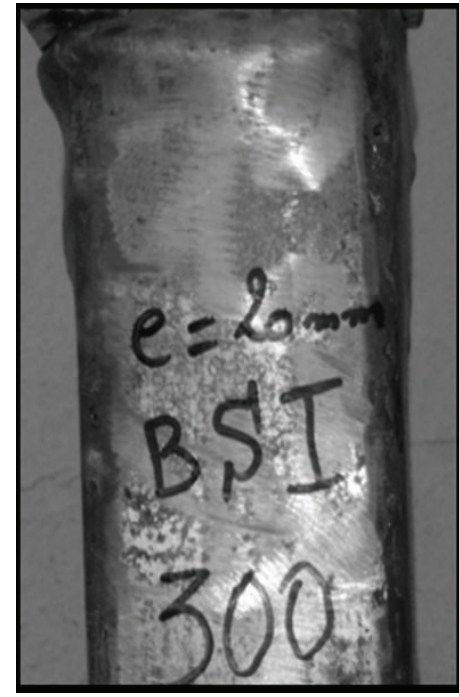

(b) BSI column, eccentricity $e=20 \mathrm{~mm}$

FIgURE 10: Failure mode of BSII column.

and Uy [13] of different columns is exposed. Results of load carrying capacity calculated by the two methods cited above show that both methods under-estimate the load carrying capacity compared with experimental results for almost all columns tested in this work. This underestimation of load imposes an acceptable safe level for estimating the bearing capacity of columns, which allows us to be on the safe side. The local buckling forming position varies from column to another but is generally around $1 / 3$ of column height counted from top surface in the case of columns tested to axial load. In the case of columns tested to eccentric load, the position of local buckling is at $1 / 4$ of column height in the direction of eccentric load, and at around 1/6 of stubs height in the opposite direction. Welding opening signs and a concrete breakdown were seen in the local buckling formation areas.

\section{Conclusion}

This study has highlighted the axial and eccentric behavior of thin steel tubes welded and filled with three types of concrete: regular concrete appointed by $\mathrm{BO}$, sand slag concrete made from $100 \%$ crystal sand slag designated by BSI, and concrete sand slag used in the concrete composition partially designated by BSII. After analyzing the results, we can highlight the following. Results show that the column strengths increase as the stubs height decreases. We see in all columns tested in this 
work the sign of local buckling developed when the ultimate bearing capacity is reached causing the instability of columns. The load carrying capacity iscalculated according Eurocode 4 prediction [14] and design method developed by Vrcelj and Uy [13]

(i) Filling the hollow tubes by various types of sand slag concretes (BSI or BSII) improved behavior and increased bearing capacity relative to the empty steel tubes and tubes filled with $\mathrm{BO}$ concrete.

(ii) The bearing capacity decreases when slenderness increases.

(iii) The bearing capacity of composite stubs is strongly influenced by the load eccentricity in the case of three types of BO concrete, BSI, and BSII.

(iv) The posts of the failure mode in the case of three types of concrete used are a way of convex local buckling accompanied by a burst of weld welding buckling training level.

(v) The bearing capacity calculated by the Euro code 4 and design Vrcelj method are an acceptable approach compared to that recorded experimentally.

\section{Competing Interests}

The authors declare that they have no competing interests.

\section{References}

[1] D. Ashura, Contribution to the study of the formulation and characterization of concretes slag based sand blast furnace EL HADJAR [Ph.D. thesis], University of Annaba, 2005.

[2] D. Achoura and B. Redjel, "Concrete Sand: characterization and behavior," in Proceedings of the 1st Symposium Maghreb Civil Engineering, pp. 17-25, University of Annaba, November 1999.

[3] A. Benaissa, Deferred deformation sand concrete [Ph.D. thesis], Civil Engineering, University of Bordeaux, 1992.

[4] R. Dupain, R. Lanchon, and S. J. C. Arroman, "Aggregates, soils, cement and concrete," in Characterization of Civil Engineering Materials by Laboratory Tests, Casteilla, Paris, France, 2004.

[5] H. Shakir-Khalil and J. Zeghiche, "Experimental behaviour of concrete-filled rolled rectangular hollow section columns," Journal of the Institution of the Structural Engineer, vol. 67, no. 19, pp. 346-353, 1990.

[6] J. G. Dreux and FESTA, New Guide of Concrete and Its Constituents, Eyrolles, Paris, France, 8th edition, 1998.

[7] H. S. Khalil, "Push-out strength of concrete filled steel hollow section," Journal of the Structural Engineer, vol. 71, no. 13, pp. 234-241, 1993.

[8] H. S. Khali, "Mouli, further tests on concrete-filled rectangular hollow section columns," Journal of the Structural Engineer, vol. 68, no. 20, pp. 405-413, 1990.

[9] J. Zeghiche, "Further tests on thin steel and composite fabricated stubs," Journal of Constructional Steel Research, vol. 81, pp. 124-137, 2013.

[10] C. Morrison, R. Hooper, and K. Lardner, "The use of ferrosilicate slag from ISF zinc production as a sand replacement in concrete," Cement and Concrete Research, vol. 33, no. 12, pp. 2085-2089, 2003.
[11] N. Robeyst, E. Gruyaert, C. U. Grosse, and N. De Belie, "Monitoring the setting of concrete containing blast-furnace slag by measuring the ultrasonic p-wave velocity," Cement and Concrete Research, vol. 38, no. 10, pp. 1169-1176, 2008.

[12] E. Gruyaert, P. Van Den Heede, M. Maes, and N. De Belie, "Investigation of the influence of blast-furnace slag on the resistance of concrete against organic acid or sulphate attack by means of accelerated degradation tests," Cement and Concrete Research, vol. 42, no. 1, pp. 173-185, 2012.

[13] Z. Vrcelj and B. Uy, "Strength of slender concrete-filled steel box columns incorporating local buckling," Journal of Constructional Steel Research, vol. 58, no. 2, pp. 275-300, 2002.

[14] Eurocode 4, "Design of composite steel and concrete structures, part1.1: general rules and rules for buildings," The European Union per Regulation EN 1994-1-1, 2004. 

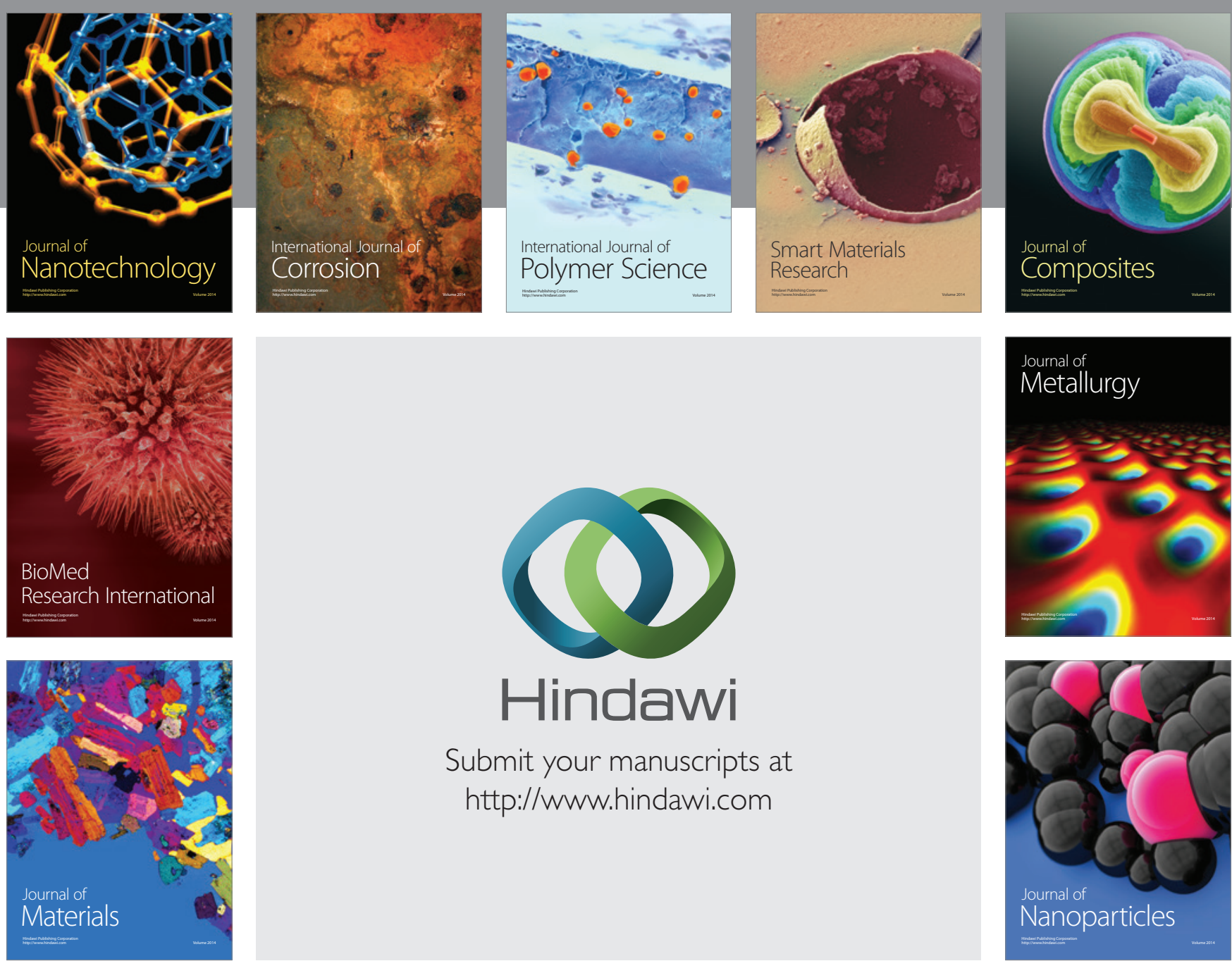

\section{Hindawi}

Submit your manuscripts at

http://www.hindawi.com

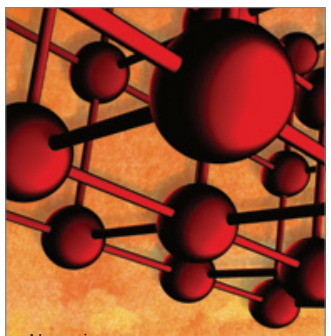

Materials Science and Engineering
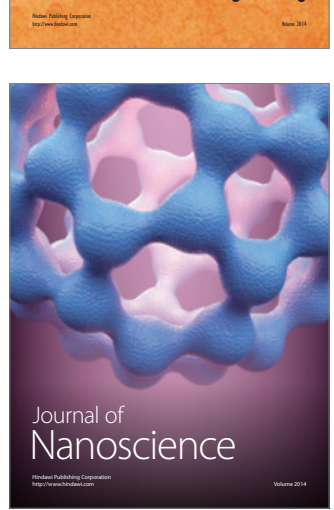
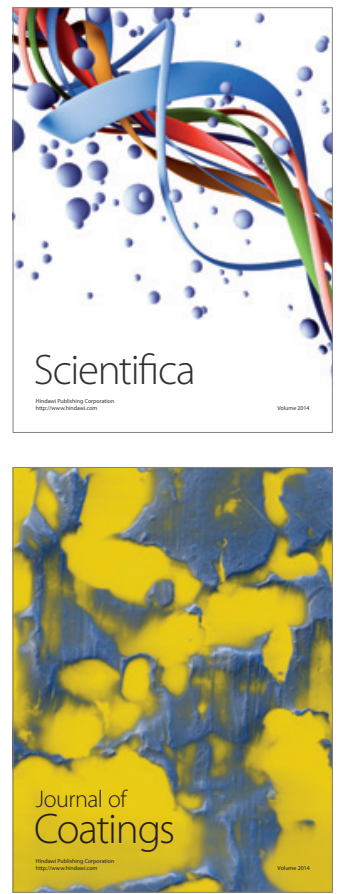
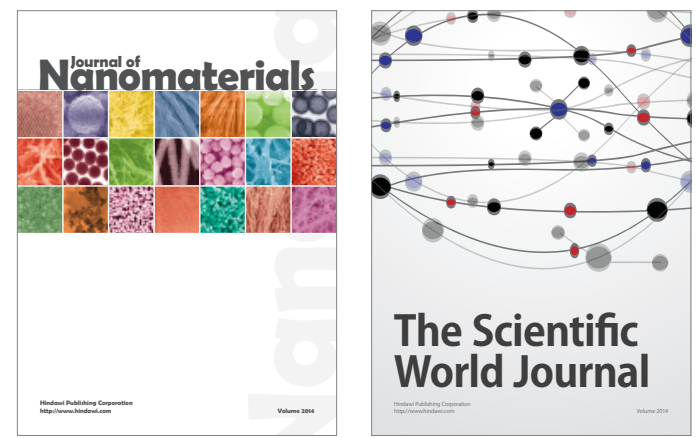

The Scientific World Journal
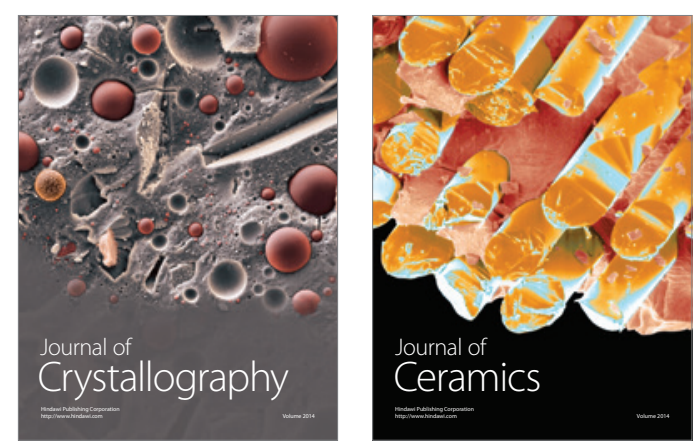
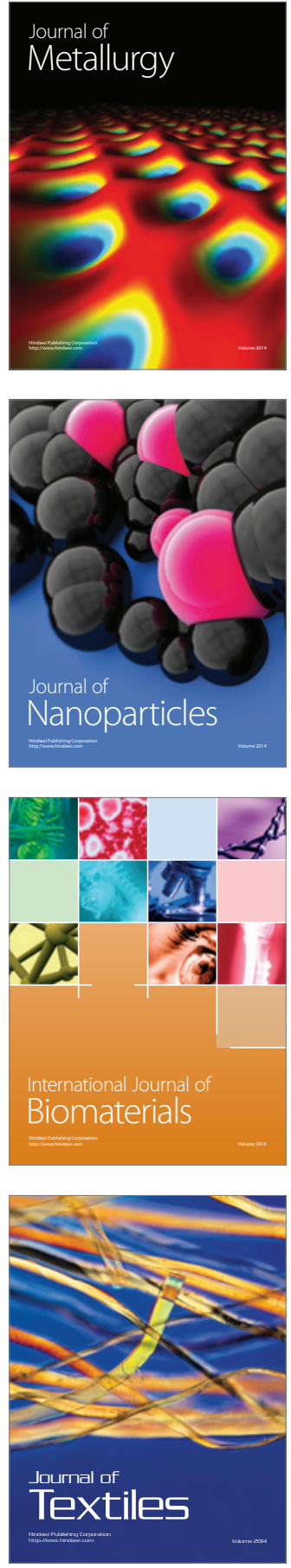